7. Reprod. Fert. (1973) 35, 445-451

\title{
THE METABOLIC ACTIVITY OF THE BOVINE EPIDIDYMIS
}

\section{UTILIZATION OF ACETATE, SUCGINATE, PYRUVATE, LAGTATE AND GLUGOSE}

\author{
T. T. TURNER AND A. D. JOHNSON \\ Animal Science Department, Livestock-Poultry Building, \\ University of Georgia, Athens, Georgia 30601, U.S.A.
}

(Received 3rd November 1972)

\begin{abstract}
Summary. The epididymides of five mature bulls were unilaterally ligated at the efferent ductules, divided into five zones and subjected to a radiorespirometric study. The metabolism in vitro of $\left[1-{ }^{14} \mathrm{C}\right]$ acetate (A-1), $\left[1-{ }^{14} \mathrm{C}\right]$ pyruvate $(\mathrm{P}-1),\left[1-{ }^{14} \mathrm{C}\right]$ lactate $(\mathrm{L}-1),\left[1-{ }^{14} \mathrm{C}\right]$ succinate $(\mathrm{S}-1)$, and $\left[1-{ }^{14} \mathrm{C}\right]$ glucose $(\mathrm{G}-1)$ was determined for normal and spermfree bovine epididymal tissue.

The relationship of ${ }^{14} \mathrm{CO}_{2}$ evolution among the substrates was as follows: P-1 > L-1 > S-1 > A-1 > G-1. The data showed that utilization of Krebs' cycle intermediates proceed at a greater rate than utilization of glucose. There was a significantly higher $(P<0 \cdot 01){ }^{14} \mathrm{CO}_{2}$ evolution by the control tissues than the treated tissues. Zone 3 of both the treatment and control epididymides utilized more individual substrates at a significantly higher $(P<0.05)$ rate than any other zone.
\end{abstract}

\section{INTRODUCTION}

The physiology and metabolic activity of the epididymis and its luminal contents has been the subject of many investigations (reviewed by OrgebinCrist, 1969; Waites \& Setchell, 1969). Studies concerning the metabolism of specifically labelled glucose compounds by epididymal tissue have been conducted by Johnson \& Turner (1971), Kraft \& Johnson (1972) and Turner \& Johnson (1973).

Acetate utilization by epididymal tissues of the rat, rabbit and mouse was found to be relatively high by Kraft \& Johnson (1972). Using mouse epididymal homogenates, Elliot (1965a) noted a relatively high $\mathrm{O}_{2}$ uptake in the presence of succinate relative to citrate and isocitrate. It was suggested that a metabolic block might exist between citrate and $\alpha$-ketoglutarate in this tissue. Studies using other substrates involved in aerobic glycolysis in conjunction with epididymal tissue are few; however, it is informative to note that the utilization of acetate, succinate, pyruvate and lactate by testicular tissue and testicular, epididymal and ejaculated spermatozoa has been investigated. While these tissues are certainly not analogous to epididymal tissue, they all have the 
possibility of influencing epididymal metabolism since the epididymal tubule contains spermatozoa and other products of testicular tissue. Acetate, for example, was found by Scott, White \& Annison (1962) to increase the respiration of ruminant spermatozoa more than glucose. This is in contrast to a later study in vivo on the ram by Annison, Scott \& Waites (1963) where testicular and epididymal tissue utilized uniformly labelled glucose in preference to uniformly labelled acetate. In studies on testicular tissue, pyruvate has been shown to cause greater $\mathrm{O}_{2}$ uptake than glucose (Elliot, Greig \& Benoy, 1937; Serfaty \& Boyer, 1956). Lactate also has been shown to cause greater $\mathrm{O}_{2}$ uptake than glucose (Elliot et al., 1937). In a study on ejaculated ram spermatozoa, O'Shea \& Voglmayr (1970) also found that lactate and acetate caused greater $\mathrm{O}_{2}$ uptake than glucose.

This investigation involved radiorespirometric measurement of ${ }^{14} \mathrm{CO}_{2}$ evolution from specifically labelled acetate, succinate, pyruvate, glucose and lactate by tissue from five zones of the normal and efferentiectomized bovine epididymis.

\section{MATERIALS AND METHODS}

Utilizing the method previously described by Turner \& Johnson (1973), the epididymides of five mature bulls were unilaterally ligated at the efferent ductules. The contralateral epididymis of each bull served as a control. After a 1-month delay and electroejaculation to ensure sperm clearance of the 'treatment' (ligated) epididymis, the epididymides were removed. The histological appearance of this tissue has been previously presented (Turner \& Johnson, 1973). Using the tissue sampling technique and radiorespirometric procedure of Turner \& Johnson (1973), the rate of $\mathrm{CO}_{2}$ evolution by epididymal tissue in vitro was determined with ${ }^{14} \mathrm{C}$-labelled substrates. For the purposes of this study, the epididymis was divided into five zones (proximal caput epididymidis, distal caput epididymidis, corpus epididymidis, proximal cauda epididymidis and distal cauda epididymidis). The zones were separated into 3- to 5-mg samples and incubated in the various substrates for 1 to $5 \mathrm{hr}$ at $35^{\circ} \mathrm{C}$ followed by a sixth collection of the residual ${ }^{14} \mathrm{CO}_{2}$ from the tissue and fluids. The substrates used and their specific activities were as follows: $\left[1-{ }^{14} \mathrm{C}\right]$ acetate $(\mathrm{A}-1)$, $1.0 \mu \mathrm{Ci} / \mu \mathrm{mol} ;\left[1-{ }^{14} \mathrm{C}\right]$ pyruvate $(\mathrm{P}-1), 6.4 \mu \mathrm{Ci} / \mu \mathrm{mol} ;\left[1-{ }^{14} \mathrm{C}\right]$ lactate $(\mathrm{L}-1)$, $5.3 \mu \mathrm{Ci} / \mu \mathrm{mol} ;\left[1-{ }^{14} \mathrm{C}\right]$ succinate $(\mathrm{S}-1), 10 \cdot 6 \mu \mathrm{Ci} / \mu \mathrm{mol} ;$ and $\left[1-{ }^{14} \mathrm{C}\right]$ glucose (G-1), 47.8 $\mu \mathrm{Ci} / \mu \mathrm{mol}$. While it was realized that labelled $\mathrm{CO}_{2}$ evolution from these substrates theoretically would not be equivalent, the rates of ${ }^{14} \mathrm{CO}_{2}$ collection were predictable in that the labelled $\mathrm{C}$ atoms come off at known positions either between pyruvate and acetyl Co-A or within the Krebs' cycle proper. Collections of ${ }^{14} \mathrm{CO}_{2}$ were made at hourly intervals for each zone and metabolic activity was evaluated through use of a liquid scintillation counter. Data resulting from this study were subjected to least squares analysis of variance followed by Duncan's Multiple Range Test to determine points of significant difference.

\section{RESULTS}

Text-figures 1 to 5 illustrate the hourly recovery rates of four specifically 
labelled substrates involved directly or indirectly with the Krebs' cycle and one labelled glucose compound. It should be noted that although the availability of the substrates at the cellular level is probably less than that which could be provided by the circulatory system, the small segments of the tissue samples provided a large surface area through which the substrates could penetrate. It was felt that this would provide adequate substrate availability for cells not directly exposed to the tissue surface.

The ${ }^{14} \mathrm{CO}_{2}$ evolution is described for tissues from five zones of control and ligated epididymides. The relationship of ${ }^{14} \mathrm{CO}_{2}$ recovery rates between substrates was as follows: P-1 $>\mathrm{L}-1>\mathrm{S}-1>\mathrm{A}-1>\mathrm{G}-1$. With the exception of L-1, which showed no significant difference between treatments, zones, or times of incubation, all substrates showed a significant increase $(P<0.01)$ in utilization by the control tissues over the ligated, or treatment tissues. There were also significant differences $(P<0.01)$ in substrate utilization between zones: G-1, A-1 and P-1 had a significantly higher utilization in Zone $3(P<0.05$; Text-figs $3 \mathrm{a}$ and $3 \mathrm{~b})$; G-1 and P-1 were utilized significantly less $(P<0.05)$ in Zone 1 (Text-figs $1 \mathrm{a}$ and $1 \mathrm{~b}$ ) when compared to other zones; S-1 was utilized most in Zone 1 and least in Zone $3(P<0 \cdot 05)$; Zone 2 utilized significantly less of G-1 and A-1 $(P<0.05)$ compared to the other zones. There were no significant
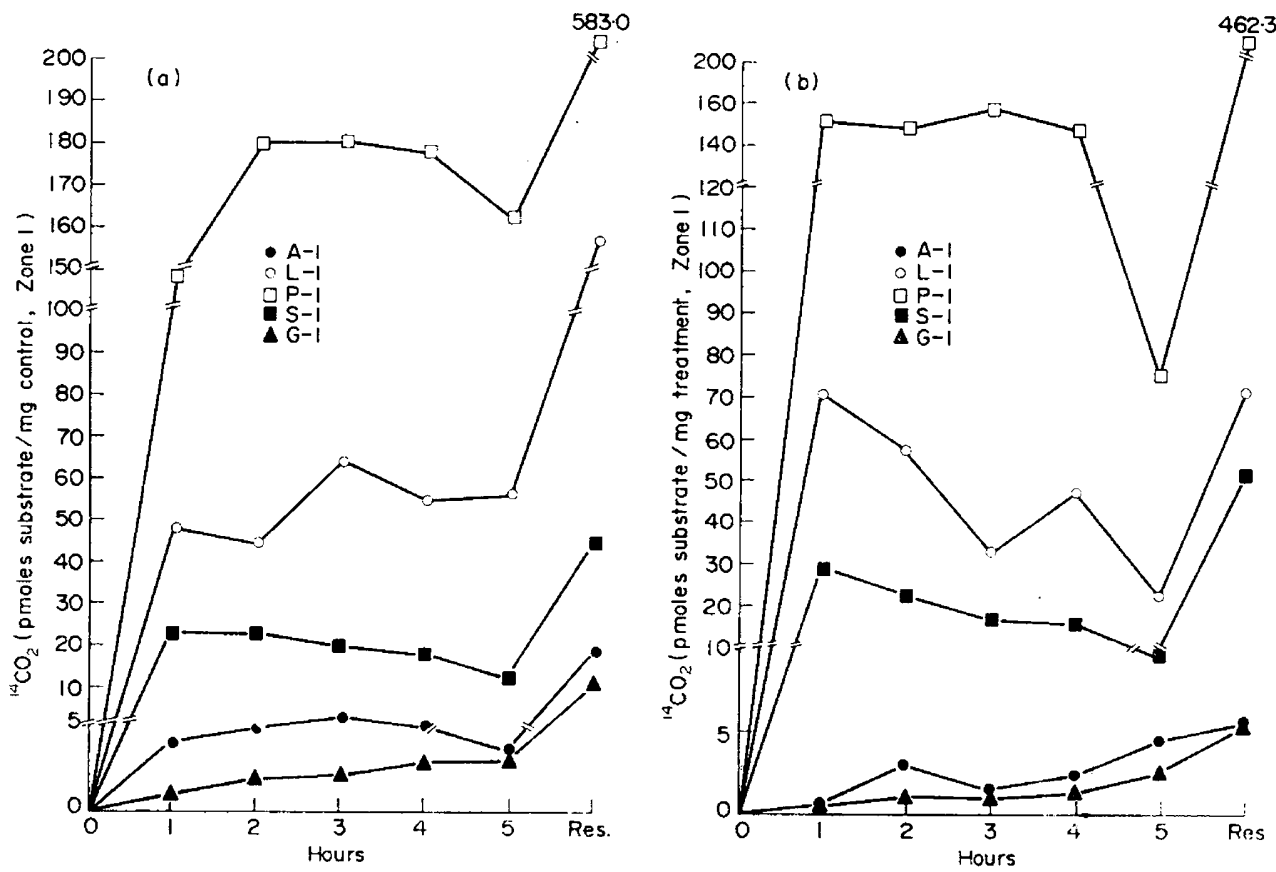

TEXT-FIG. 1

Text-figs 1 to 5. Epididymal zones 1 to 5, respectively. Hourly and residual (Res.) ${ }^{14} \mathrm{CO}_{2}$ evolution from specifically labelled acetate, succinate, pyruvate, lactate and glucose in (a) control and (b) treatment tissues. 

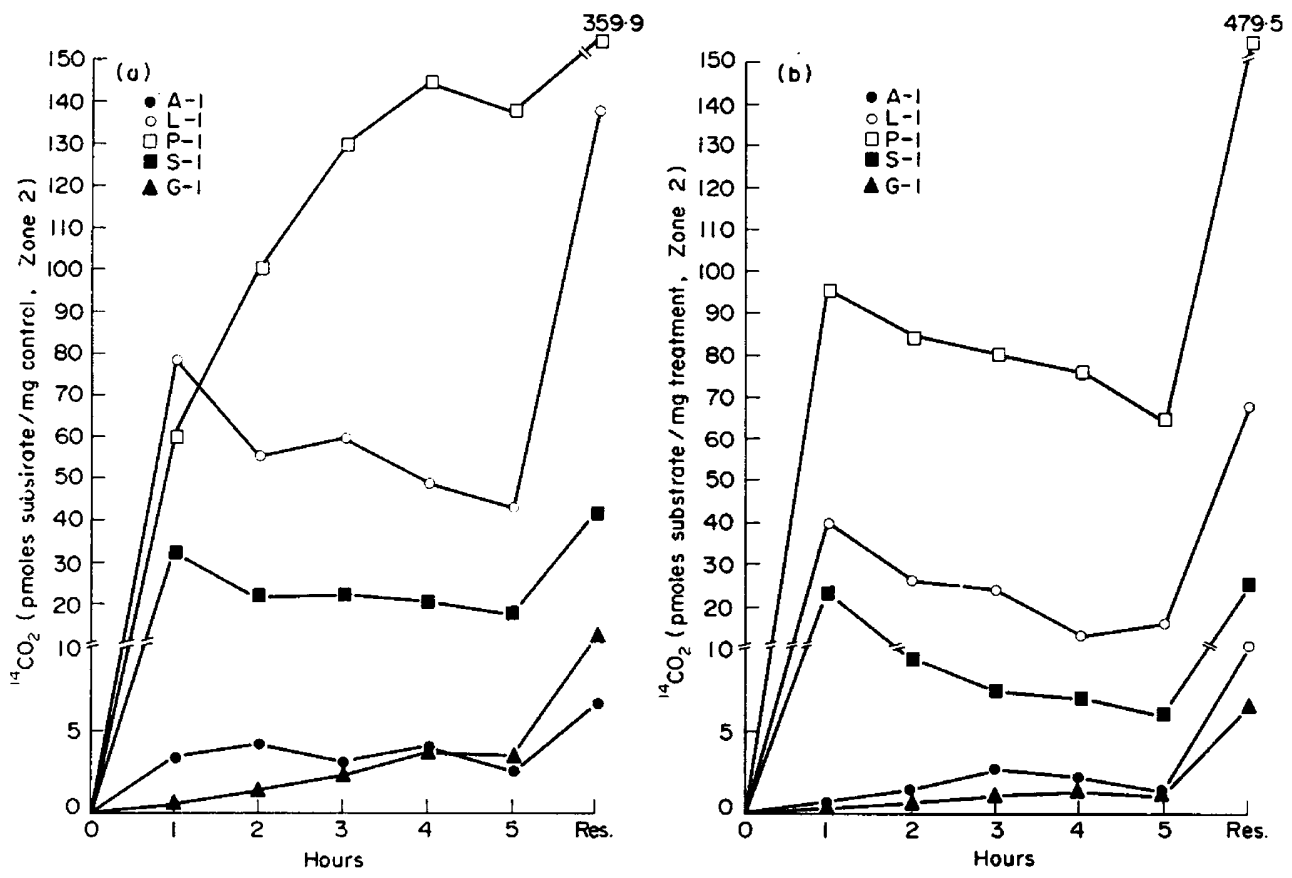

TeXT-FIG. 2
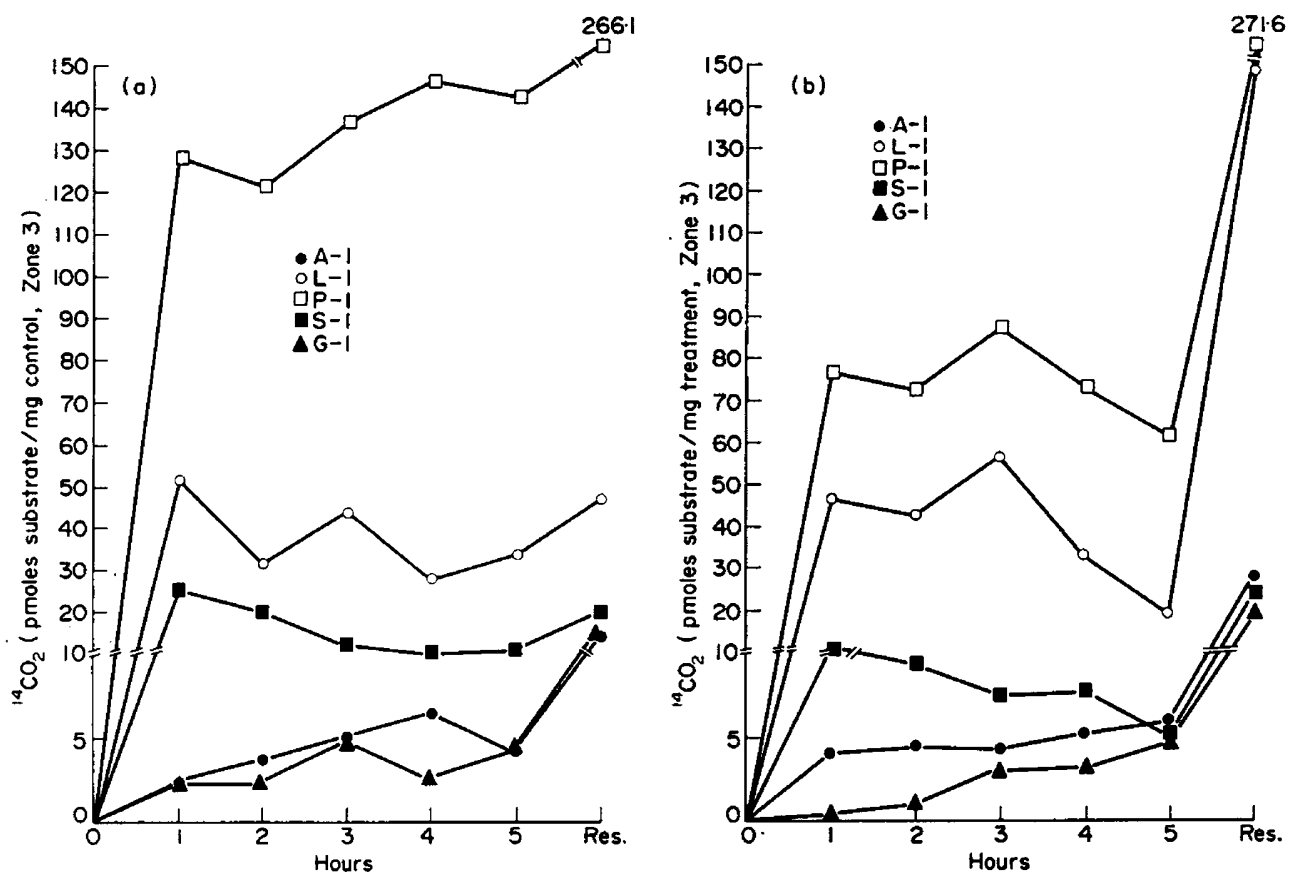

TEXT-FIG. 3 


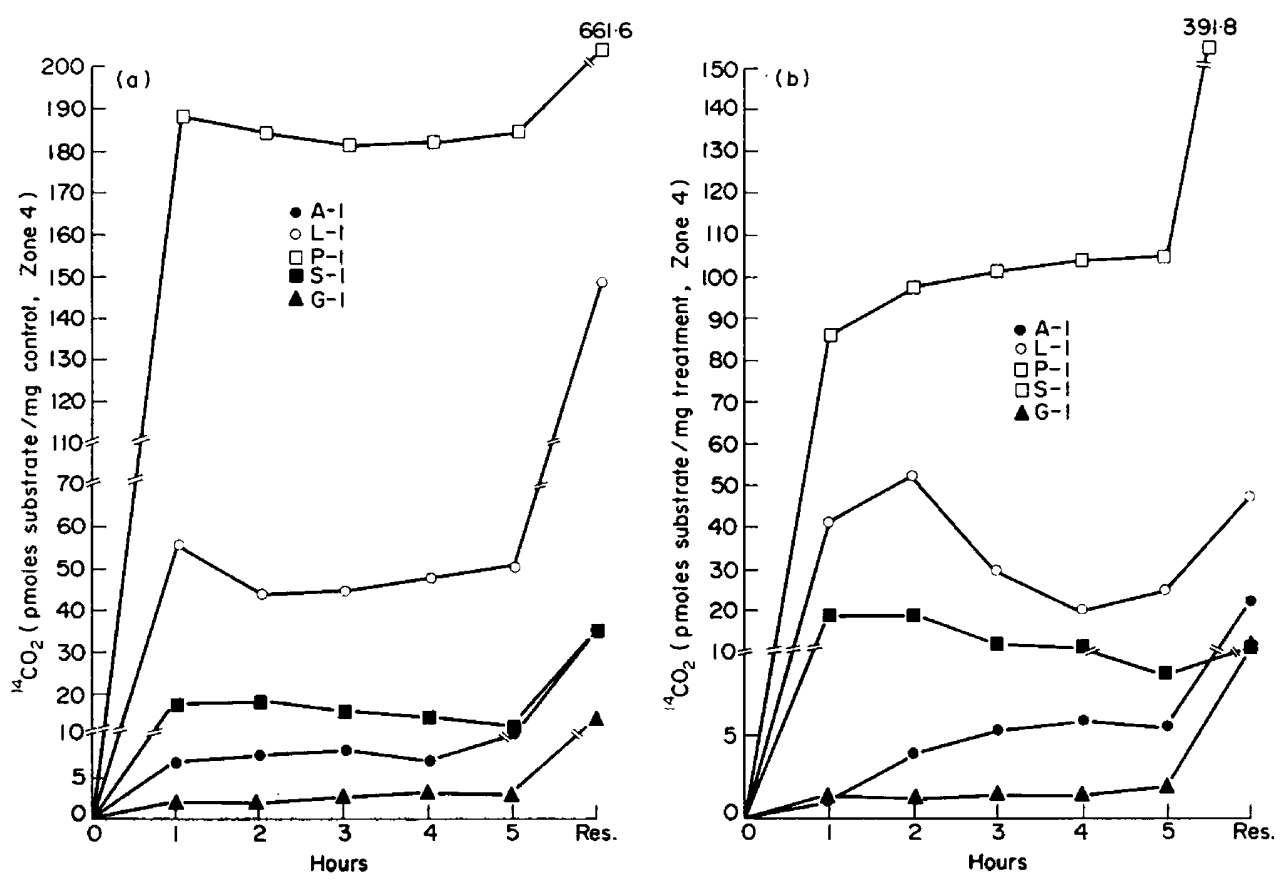

TEXT-FIG. 4
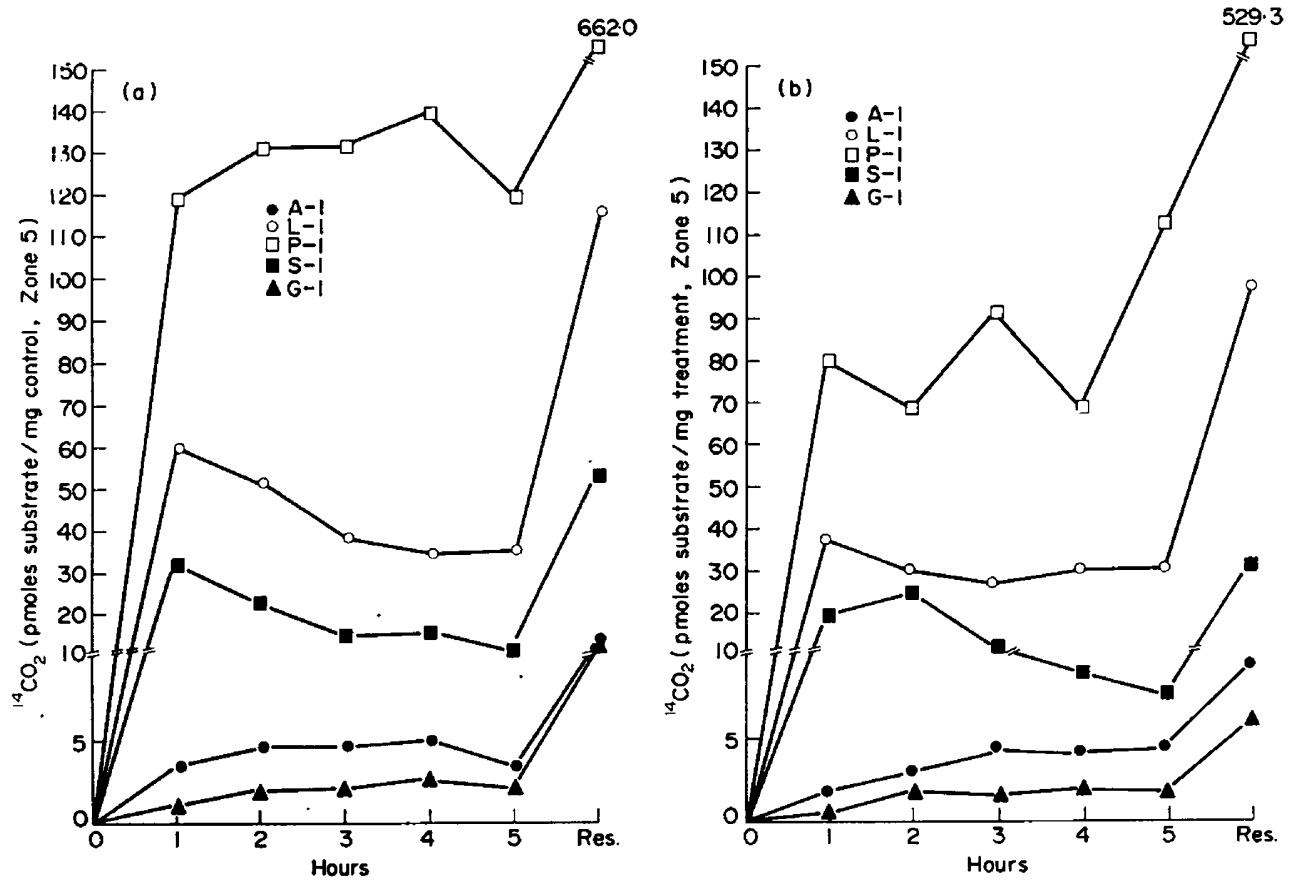

TeXt-Fig. 5 
differences in ${ }^{14} \mathrm{CO}_{2}$ evolution rates between collection hours except for the increased ${ }^{14} \mathrm{CO}_{2}$ evolution at the residual collection $(P<0.05)$ and significantly less utilization of G-1 during the first hour $(P<0.05)$.

Comparison of overall ${ }^{14} \mathrm{CO}_{2}$ evolution within hours showed that there was always a significant difference $(P<0 \cdot 05)$ between treatment and control tissues except at the 5-hr and residual collections. The residual collection approached significance, but the 5-hr collection showed no significant difference between treatments, zones or substrates. In all cases, the control tissues were higher in substrate oxidation. This was demonstrated by the control: treatment ${ }^{14} \mathrm{CO}_{2}$ evolution ratios for P-1, L-1, S-1, A-1 and G-1 by cauda epididymidis tissue during the 5 th hour of incubation. The values were $1 \cdot 8,2 \cdot 0$, $1.5,1.9$ and $1 \cdot 7$, respectively. Compared within hours, there were no significant differences between zones in substrate oxidation rate with the exception of the 3rd hour which showed the rate to be significantly higher in Zone $1(P<0.05)$; Zone 1 also produced the highest amount of ${ }^{14} \mathrm{CO}_{2}$ in treatment and control tissues throughout the collection period.

There was a significant difference $(P<0.01)$ in total utilization of substrates shown within hours. At all collections, P-1 and L-1 were significantly higher $(P<0.05)$ in ${ }^{14} \mathrm{CO}_{2}$ evolution and $\mathrm{S}-1, \mathrm{~A}-1$ and $\mathrm{G}-1$ followed in descending order.

\section{DISCUSSION}

Lardy, Hansen \& Phillips (1945) found that the substrates used in their study stimulated $\mathrm{O}_{2}$ uptake in epididymal spermatozoa in the following order: pyruvate $>$ lactate $>$ succinate $>$ acetate. The order of preference of utilization by epididymal tissue found in this study was P-1 $>$ L-I $>$ S-1 $>$ A-1. It was also shown that the above substrates, which are involved with the Krebs cycle intermediates, evolve ${ }^{14} \mathrm{CO}_{2}$ at a higher rate than G-1. This order of tissue preference for substrate is indicative of standard Krebs' cycle activity. In an earlier study, Turner \& Johnson (1973) found that the ${ }^{14} \mathrm{CO}_{2}$ evolution of G-3,4 ([3,4- $\left.{ }^{14} \mathrm{CO}_{2}\right]$ glucose) approached the rate shown for $\mathrm{S}-1$ in this study. Other researchers have shown a higher preference for Krebs' cycle intermediates than for glucose by spermatozoa (O'Shea \& Voglmayr, 1970), testicular tissue (Serfaty \& Boyer, 1956) and epididymal homogenates (Elliot, 1965b). Whereas this study found acetate to be utilized preferentially to glucose, Annison et al. (1963) in a study on ram testicular and epididymal metabolism in vivo found uniformly labelled acetate to be utilized at a lower rate than uniformly labelled glucose.

From the results of his study on rat epididymal tissue, Elliot (1965a) suggested the occurrence of a metabolic block between citrate and $\alpha$-ketogluterate. In the present study, P-1 and L-1 were always utilized at a higher rate than succinate, a finding which does not appear to support those of Elliot. Oxidation of A-1 was relatively low in this study as compared to the report of Kraft \& Johnson (1972) who found a much higher rate of ${ }^{14} \mathrm{CO}_{2}$ evolution from A-1 in the caput and cauda epididymidis of the rat, rabbit and mouse.

The treatment tissues of this study showed a lower utilization of substrates than did the control tissues. This may have been due to the absence of sperma- 
tozoa in the treatment tissues (Elliot, 1965b). This appeared to be true for all substrates except L-1, which showed no significant differences in utilization between hours, zones or treatments. All areas of the epididymis may, therefore, be assumed to have sufficient lactate dehydrogenase present to utilize lactate extensively as an energy source. When compared within hours, Zone 1 was always highest in the total utilization of all substrates though not to the point of significant difference. This high metabolic rate persisted to a lesser degree even in the treatment tissues, indicating high substrate utilization by the epididymal epithelium. Zone 3 utilized three of the five substrates at a significantly higher rate $(P<0.01)$ than any other zone. This may point again to the particularly active nature of Zone 3 which has been discussed in a previous paper (Turner \& Johnson, 1973).

\section{ACKNOWLEDGMENTS}

Grateful appreciation is extended to Mr Rick Evans, Mr Fu Shih Huang, Mr Steve Hancock and Mr Terry Ackroyd for their assistance during the course of this experiment.

\section{REFERENCES}

Annison, E. F., Scott, T. W. \& Waites, G. M. H. (1963) The role of glucose and acetate in the oxidative metabolism of the testis and epididymis of the ram. Biochem. F. 88, 482.

Elliot, P. R. (1965a) The metabolism of homogenates of the mouse epididymis. $\mathcal{F}$. cell. comp. Physiol. 66, 281.

ELLIOT, P. R. (1965b) Effect of efferentiectomy and orchidectomy on the metabolism of the epididymis of the mouse. F. cell. comp. Physiol. 66, 293.

Elliot, K. A., Greig, M. E. \& Benoy, M. P. (1937) The metabolism of lactic and pyruvic acids in normal and tumor tissues. III. Rat liver, brain and testis. Biochem. J. 31, 1103.

Johnson, A. D. \& TURner, P. C. (1971) Epididymal carbohydrate metabolism. I. Glucose-1 $-{ }^{14} \mathrm{C}$ and glucose- $6-{ }^{14} \mathrm{C}$ metabolism by mouse, rat and rabbit tissues. Comp. Biochem. Physiol. 39A, 599.

Kraft, L. A. \& Johnson, A. D. (1972) Epididymal carbohydrate metabolism. II. Substrates and pathway utilization of caput and cauda epididymal tissue from the rabbit, rat and mouse. Comp. Biochem. Physiol. 42B, 451.

Lardy, H. A., Hansen, R. G. \& Phillips, P. H. (1945) The metabolism of bovine epididymal sperm. Archs Biochem. 6, 41.

Orgebin-Crist, M. C. (1969) Studies on the function of the epididymis. Biol. Reprod. 1, 155.

O'Shea, T. \& Voglmayr, J. K. (1970) Metabolism of glucose, lactate and acetate by testicular and ejaculated spermatozoa of the ram. Biol. Reprod. 2, 326.

Scott, T. W., Whrte, I. G. \& Annison, E. F. (1962) Glucose and acetate metabolism by ram, bull, dog and fowl spermatozoa. Biochem. 7. 82, 398.

SERFATY, A. \& BOYER, J. (1956) L'influence de divers métabolites glucidiques sur l'intensité respiratoire du testicule de rat blanc. Experientia, 12, 386.

TURner, T. T. \& Johnson, A. D. (1973) The metabolic activity of the bovine epididymis. I. Utilization of glucose and fructose. F. Reprod. Fert. 34, 203.

Waites, G. M. H. \& Setchell, B. P. (1969) Physiology of the testis, epididymis and scrotum. Adv. reprod. Physiol. 4, 1. 